
\title{
25 Research Square \\ Heating Rate Effect during Sintering on the Technological Properties of Brazilian Red Ceramics
}

\section{Carlos Guimarães}

UENF - State University of the Northern Rio de Janeiro

\section{Geovana Delaqua}

UENF - State University of the Northern Rio de Janeiro

Afonso Rangel Garcez de Azevedo ( $\sim$ afonso.garcez91@gmail.com )

UENF: Universidade Estadual do Norte Fluminense Darcy Ribeiro

\section{Sergio Neves Monteiro}

IME - Military Institute of Engineering, IME

\section{Lucas Amaral}

UENF - State University of the Northern Rio de Janeiro

Claudio Luiz Melo Souza

UENF - State University of the Northern Rio de Janeiro

\section{Angelus da Silva}

UENF - State University of the Northern Rio de Janeiro

José Nilson Holanda

UENF - State University of the Northern Rio de Janeiro

Carlos Maurício Fontes Vieira

UENF - State University of the Northern Rio de Janeiro

\section{Research Article}

Keywords: Brazilian clay, ceramic, Firing cycle, Fast sintering, Roofing tile, Red ceramic

Posted Date: November 11th, 2021

DOI: https://doi.org/10.21203/rs.3.rs-1051063/v1

License: (c) (1) This work is licensed under a Creative Commons Attribution 4.0 International License.

Read Full License 


\section{Abstract}

Unbalanced energy consumption in the production of ceramic artifacts is responsible for considerable undesirable impacts, such as increased emissions of polluting gases, excessive consumption of fuel materials, land degradation and unpredictable financial costs. By contrast, the practice of optimizing the ceramic sintering, which in associated with firing of high temperature, can result in increased productivity and reduced production costs preserving an environmentally friendly production system. Moreover, it allows further improvements in the quality of the final product. This work compares the effect of different sintering cycles, with heating rates of 2,15 and $30^{\circ} \mathrm{C} / \mathrm{min}$, on the technological properties of a Brazilian industrial clay ceramic body. Initially the clay ceramic specimens was characterized in terms of mineralogical, chemical and physical properties. Specimens were prepared by extrusion and fired at temperatures of 800,900 and $1000^{\circ} \mathrm{C}$. The evaluated properties by standard tests were water absorption, post-firing linear shrinkage and flexural strength. It was found that owing to sintering carried out at higher heating rates, red ceramic products with superior technological properties were obtained. This is an unprecedented conclusion for common clay ceramics produced in Brazil. Based on the promising obtained results it is evidenced, in a clear and detailed way, the benefits of rapid sintering cycle application for conventional brick production.

\section{Introduction}

The Brazilian ceramic sector has a significant economic relevance for the country, mainly in the generation of jobs and regional income as well as a support to building construction. This sector is not only one of the world largest but also diversified in products comprising several segments [1-3]. The most important products are abrasives, bioceramics, sanitary ware, refractory materials, ceramic coatings and clay ceramic with reddish color, commonly known as red ceramics $[1,2]$. The segment of red ceramics includes materials used in building construction, such as bricks, blocks, tiles, pipes and hollow elements $[1,3]$. All of them obtained by sintering, which usually confers the typical a reddish color owing to the iron high content. Red ceramics are categorized in the non-metallic minerals sector of the Brazilian mineral processing industry as associated with the civil engineering production chain [3-7]. It involves approximately 7,000 companies, most of them micro or small family-owned enterprises that are responsible for almost 300 thousand direct jobs, with annual revenues around 5 billion US dollars [3, 4]. In the turning of the century, along 1990 and 2011, the per capita consumption of the products of the red ceramic segment in Brazil increased by $350 \%$ [4]. Currently, the country`s construction industry, as the main driver of the national red ceramic segment, is facing unfavorable economic condition. Thus, reducing production costs through technological innovations in processing is the current strategy for the segment to stay competitive in the market.

Studies have shown that optimizing the sintering step of ceramic parts considerably reduces the financial costs of the process, at least by about $20 \%$, which is a highly favorable feature in a scenario of economic crisis $[8,9]$. Another relevant aspect of the production of ceramic artifacts refers to environmental issues. Indeed, the traditional red clay ceramic production processes involving raw material mixing, processing, 
shaping, and firing generate a huge environmental liability. For example, the extraction of raw materials such as clay might cause permanent soil degradation while firing impairs air quality with emission of toxic gases. Firing, in particular impairs air quality, with emissions of toxic gases while the extraction of raw materials such as clay might cause permanent soil degradation [10,11]. Firing, in particular corresponds to the main stage to consolidate the red ceramic structure and develop properties by mechanisms in solid state sintering [12].

The sintering is a fundamental processing stage in the ceramic production and significantly related to the quality of the final product $[9,12-14]$. In addition, this stage is the one with the largest economical participation in the production chain. A rapid sintering cycle contributes not only to reduce cost but also to quickly generate thermal energy and efficiently transmit it from the surface to the interior of the ceramic piece. This accelerates the physical and chemical reaction responsible for consolidating the ceramic structure $[9,15,16]$.

Worldwide, in most modern large-scale advanced ceramic tile industries the production is already carried out through the rapid sintering cycle process in roller kilns [17]. Small-scale common clay ceramic industries, however, still use dry pressing conformation process, typical of their traditional practice for bricks production $[17,18]$. The implementation of the rapid sintering was consolidated since the 80's in the sector of ceramic tiles and sanitary wares [19]. Previously, this process was carried out slowly, in the whole segment of ceramics production. Today, this technology is comparable to that of reference countries, such as Italy and Spain [18]. Regarding the Brazilian industrial sector of common red ceramics, no significant technological improvements have been made since its implementation, from the second half of the twentieth century. It consists mostly of small and medium-sized companies with limited mechanization. Indeed, only relatively few Brazilian companies employ the rapid sintering cycle in the specific production of tiles and sanitary wares [4].

Today Brazil produces a huge number of red ceramic pieces, which are generally applied in civil construction, such as structural blocks and bricks. One of the major problems related to the clay ceramic products is their low added value and the simplicity of the industries in the sector [20]. Among the largest production centers of red ceramics in Brazil stands the one located in Campos dos Goytacazes (Campos for short), state of Rio de Janeiro, Brazil, with large clay deposits, which motivated the development of the local red ceramic industry. Campos also benefits from available natural gas, as firing fuel, and the proximity to the metropolis of Rio de Janeiro, the second largest consumer market in the country [21]. The Campos ceramic industries are mainly focused on the manufacture of red brick, a low-added value product that corresponds to $90 \%$ of their production. In addition, there is also a small manufacture of roofing tiles, extruded floors, cladding plates, all from local clays and structural block [22].

The Campos clays present, as their main characteristics, the predominance of kaolinite mineral with high plasticity [23]. Local industrial clay ceramic body masses are generally empirically elaborated by mixing of "strong" and "weak", i.e., more and less plastic clays, respectively. Eventually, some industries use quartz, sand in the clay ceramic, mass mixture. The composition of this mixture is quite variable and 
depends on intended product to be manufactured and the characteristics of the clays $[1,2,24,25]$. As any typical Brazilian red ceramic industries, those in Campos use slow sintering rates comprising more than one day of firing.

In this scenario, the aim of the present work was a first time evaluation of the influence, in a laboratory scale, of the effect of the sintering cycle conducted with different heating and cooling rates, on the technological properties of red ceramic specimens made by extrusion, which is the typical red bricks manufacturing process by the Campos local industries.

\section{Materials And Methods}

The experimental procedure was divided into four stages. The first included collecting the different clays and sand for the mixture as well as processing and characterization of the red ceramic specimens. The second comprised the preparation of the clay body (CB) mass formulations. The third consisted of specimens conformation and firing while in the fourth stage, the sintered red ceramics physical and mechanical properties were evaluated by means of standard technological tests.

The typical CB employed in this work was collected at a brick industry in Campos. It was already prepared, mixed, laminated and stored at the ceramic industry in order to obtain samples suitable for the physical, chemical and mineralogical characterization. The precursor CB underwent a series of steps that involved drying, comminution, homogenization and sieving operations with appropriate granulometry to perform each following technological test. Conventional tests were carried out to characterize the CB: granulometry, plasticity, chemical analysis, mineralogical analysis and dilatometry, all according to Brazilian standards [26-28]. The chemical analysis was performed using X-ray fluorescence (XRF) in a Unicam Solar 969 model. The minerals identification was determined by X-ray diffraction (XRD) in a Shimadzu XRD7000 equipment, operating with Cu-Ka radiation and $2 \theta$ scan ranging from $3^{\circ}$ to $60^{\circ}$, with step of $0.02^{\circ}$ and time of $5 \mathrm{~s}$. The dilatometric test was performed on Netzsch DIL 402 PC equipment, with heating rates of 2,15 and $30^{\circ} \mathrm{C} / \mathrm{min}$ and final temperature of $1050^{\circ} \mathrm{C}$.

Prismatic specimens were formed by extrusion in a Verdés brand laboratory extruder in which the die shape has nominal dimensions of $30 \times 20 \mathrm{~cm}$ (width and height). Its length of $80 \mathrm{~cm}$ was defined by the distance between the cutting lines. To achieve the appropriate plastic consistency for conformation, $30 \%$ moisture was added to the $\mathrm{CB}$.

After shaping, the samples were dried in a laboratory oven at a temperature of $60^{\circ} \mathrm{C}$ for 24 hours and then at a temperature of $110^{\circ} \mathrm{C}$ for final drying until reaching a constant weight. The apparent dry bulk density determination was performed as per ASTM C373 [29]. Three sintering cycles were used to evaluate the influence of the heating/cooling rate on the ceramic properties. In order to verify if there is interaction between heating/cooling rates and sintering temperature, the samples were fired at 800,900 and $1000^{\circ} \mathrm{C}$ using three different heating rates of 2,15 and $30^{\circ} \mathrm{C} / \mathrm{min}$ for each temperature. After reaching the desired temperature, cooling was carried out at the same rate of heating. The sintering was carried out in a MAITEC FSCQ-1300/3 laboratory furnace, suitable for fast sintering. 
The sintered red ceramic specimens were subjected to the following tests: three-point bending flexural, water absorption, apparent porosity and sintering linear shrinkage. The flexural test was performed by three points bending in an Instron 5582 universal test machine with maximum capacity of $100 \mathrm{kN}$, operating with a constant speed of $0.5 \mathrm{~mm} / \mathrm{min}$ until the specimen was ruptured. Water absorption and apparent porosity were performed as per ASTM C373 standard [29].

For statistical analysis, considering the uniformity of the experimental environment, a randomized design with 13 replicates was used in a $3 \times 3$ factorial scheme totaling 117 experimental units. The data were subjected to the normality Lilliefors variance and to the homogeneity of Crochran\&Barttlet test. Since data transformation was not necessary, results were then examined in terms of the analysis of variance (ANOVA) and the Tukey Test (P $\leq 0.05)$.

\section{Results And Discussion}

The results of clay body (CB) mineralogical analysis by XRD are shown in Fig. 1. The diffractogram reveals that $C B$ is composed of, quartz $(\mathrm{Q})$, mica $(M)$, gibbsite $(\mathrm{Gi})$ and less intense peaks related to some potassic feldspar (Fk).

Table 1 presents the $\mathrm{CB}$ chemical analysis. One should notice the predominance of $\mathrm{SiO}_{2}, \mathrm{Al}_{2} \mathrm{O}_{3}$ and $\mathrm{Fe}_{2} \mathrm{O}_{3}$, which reveals a typical composition of clay-based raw material for red ceramics [30, 31]. However, the lower percentage of $\mathrm{Fe}_{2} \mathrm{O}_{3}$ was responsible to provide a lighter red color after sintering. In addition, it is possible to observe a relatively high percentage of $\mathrm{Al}_{2} \mathrm{O}_{3}$, which tends to increase the $\mathrm{CB}$ refractoriness, when compared to other clays used to produce roofing tiles with recognized technical quality [32]. The loss on fire (LoF) comes mainly from the dehydroxylation of the clay minerals and the gibbsite [33].

Table 1

- Chemical composition of clayey body (\% wt.)

\begin{tabular}{|rrrrrrrrrrr|}
\hline $\mathrm{SiO}_{2}$ & $\mathrm{Al}_{2} \mathrm{O}_{3}$ & $\mathrm{Fe}_{2} \mathrm{O}_{3}$ & $\mathrm{~K}_{2} \mathrm{O}$ & $\mathrm{TiO}_{2}$ & $\mathrm{MgO}$ & $\mathrm{Na}_{2} \mathrm{O}$ & $\mathrm{CaO}$ & $\mathrm{P}_{2} \mathrm{O}_{5}$ & $\mathrm{MnO}$ & LoF $^{1}$ \\
\hline 52.20 & 28.07 & 3.46 & 1.31 & 1.20 & 0.64 & 0.37 & 0.30 & 0.11 & $<0.05$ & 12.33 \\
\hline
\end{tabular}

Figure 2 - Granulometric distribution of clayey body on Winkler diagram

The apparent dry density (DD) of the clay ceramic specimens under different treatments is shown in Table 2. Statistically different variations $(P \leq 0.05)$ in $D D$, are verified when evaluating the general averages for the heating rate (HR) and the sintering temperature (ST), as well as by comparing the interaction between these two factors. In the shaping by extrusion, which is the most used method for red clay ceramic bricks production in Brazil, it is not possible to directly control the specimens' weight. The same thing happens in the shaping by pressing. Thus, variations in density may occur. 
Table 2

Apparent dry density $\left(D D-\mathrm{g} / \mathrm{cm}^{3}\right)$ of specimens as a function of sintering temperature (ST) and heating rates $(\mathrm{HR})$

\begin{tabular}{|c|c|c|c|c|}
\hline \multirow{2}{*}{$\begin{array}{l}\text { HR } \\
\left({ }^{\circ} \mathrm{C} / \mathrm{min}\right)\end{array}$} & \multicolumn{3}{|l|}{ ST $\left({ }^{\circ} \mathrm{C}\right)$} & \multirow[t]{2}{*}{ Mean } \\
\hline & 800 & 900 & 1000 & \\
\hline \multirow[t]{2}{*}{02} & $1.77 \mathrm{Cb}$ & $1.77 \mathrm{Bb}$ & $1.82 \mathrm{Aa}$ & $1.79 \mathrm{C}$ \\
\hline & $( \pm 0.02)$ & $( \pm 0.02)$ & $( \pm 0.02)$ & $( \pm 0.03)$ \\
\hline \multirow[t]{2}{*}{15} & $1.82 \mathrm{Aa}$ & $1.83 \mathrm{Aa}$ & $1.82 \mathrm{Aa}$ & $1.83 \mathrm{~A}$ \\
\hline & $( \pm 0.02)$ & $( \pm 0.01)$ & $( \pm 0.02)$ & $( \pm 0.02)$ \\
\hline \multirow[t]{2}{*}{30} & $1.80 \mathrm{Bb}$ & $1.81 \mathrm{Aab}$ & $1.82 \mathrm{Aa}$ & $1.81 \mathrm{~B}$ \\
\hline & $( \pm 0.02)$ & $( \pm 0.03)$ & $( \pm 0.02)$ & $( \pm 0.03)$ \\
\hline \multirow[t]{2}{*}{ Mean } & $1.80 \mathrm{~b}$ & $1.81 \mathrm{~b}$ & $1.82 \mathrm{a}$ & 1.81 \\
\hline & $( \pm 0.03)$ & $( \pm 0.03)$ & $( \pm 0.02)$ & $( \pm 0.03)$ \\
\hline
\end{tabular}

The water absorption (WA) values under the different treatments are shown in Table 3. As expected, an increase in ST resulted in WA reduction. However, promising results are observed when comparing the averages between the different heating rates. The increase in HR from 2 to $15^{\circ} \mathrm{C} / \mathrm{min}$ was able to reduce the WA, proportionally, by about $6.4 \%$. The $\mathrm{HR}$ of $30^{\circ} \mathrm{C} / \mathrm{min}$ was also able to reduce the WA when compared to the conventional $\mathrm{HR}\left(2^{\circ} \mathrm{C} / \mathrm{min}\right)$. However, it revealed a higher value than the intermediate $\mathrm{HR}$ $\left(15^{\circ} \mathrm{C} / \mathrm{min}\right)$.

The apparent porosity (AP), which is a parameter associated with pores interconnected with the exterior of the structure, is markedly related to the WA. In fact, an apparent inverse relationship is observed between WA and AP when comparing the results in Tables 3 and 4. It is also possible to note the existence of this inverse relationship between the DD and WA, justifying the differences associated with distinct HRs. It can be seen that the averages values of WA for each HR follow the contrary behavior of the $\mathrm{DD}$. Indeed, $\mathrm{HR}$ at $15^{\circ} \mathrm{C} / \mathrm{min}$ is related to the highest $\mathrm{DD}$, followed by $30^{\circ} \mathrm{C} / \mathrm{min}$ and $2^{\circ} \mathrm{C} / \mathrm{min}$. In the inverse way, the lowest WA was found at $\mathrm{HR}$ of $15^{\circ} \mathrm{C} / \mathrm{min}$, followed by $30^{\circ} \mathrm{C} / \mathrm{min}$ and $2^{\circ} \mathrm{C} / \mathrm{min}$. 
Table 3

Water absorption (WA - \%) of specimens as a function of sintering temperature (TQ) and heating rates (TA)

\begin{tabular}{|lllll|}
\hline HR & \multicolumn{2}{l}{ ST $\left({ }^{\circ} \mathrm{C}\right)$} & \multicolumn{2}{c|}{ Mean } \\
\cline { 2 - 4 }$\left({ }^{\circ} \mathrm{C} / \mathrm{min}\right)$ & $\mathbf{8 0 0}$ & $\mathbf{9 0 0}$ & $\mathbf{1 0 0 0}$ & \\
\hline $\mathbf{0 2}$ & $22.43 \mathrm{Aa}$ & $21.99 \mathrm{Ab}$ & $20.52 \mathrm{Ac}$ & $21.65 \mathrm{~A}$ \\
& $( \pm 0.31)$ & $( \pm 0.12)$ & $( \pm 0.49)$ & $( \pm 0.89)$ \\
\hline $\mathbf{1 5}$ & $21.51 \mathrm{Ba}$ & $20.28 \mathrm{Bb}$ & $19.25 \mathrm{Bc}$ & $20.34 \mathrm{C}$ \\
& $( \pm 0.29)$ & $( \pm 0.28)$ & $( \pm 0.33)$ & $( \pm 0.98)$ \\
\hline 30 & $22.23 \mathrm{Aa}$ & $20.39 \mathrm{Bb}$ & $19.19 \mathrm{Bc}$ & $20.60 \mathrm{~B}$ \\
& $( \pm 0.62)$ & $( \pm 0.56)$ & $( \pm 0.39)$ & $( \pm 1.37)$ \\
\hline Mean & $22.06 \mathrm{a}$ & $20.89 \mathrm{~b}$ & $19.65 \mathrm{C}$ & 20.86 \\
& $( \pm 0.58)$ & $( \pm 0.87)$ & $( \pm 0.74)$ & $( \pm 1.23)$ \\
\hline $\begin{array}{l}\text { *Means followed by the same uppercase letters in the column and lower case letters in the row, do not } \\
\text { differ according to the ANOVA and Tukey test }(\mathrm{P} \leq 0.05) .\end{array}$ \\
\hline
\end{tabular}

Table 4

Apparent porosity (AP - \%) of specimens as a function of sintering temperature (TQ) and heating rates (TA)

\begin{tabular}{|lllll|}
\hline HR & \multicolumn{2}{l}{ ST $\left({ }^{\circ} \mathrm{C}\right)$} & \multicolumn{2}{c|}{ Mean } \\
\cline { 2 - 4 }$\left({ }^{\circ} \mathrm{C} / \mathrm{min}\right)$ & $\mathbf{8 0 0}$ & $\mathbf{9 0 0}$ & $\mathbf{1 0 0 0}$ & \\
\hline $\mathbf{0 2}$ & $36.48 \mathrm{Ab}$ & $3717 \mathrm{Aa}$ & $35.10 \mathrm{Ac}$ & $36.25 \mathrm{~A}$ \\
& $( \pm 0.53)$ & $( \pm 0.15)$ & $( \pm 0.63)$ & $( \pm 0.99)$ \\
\hline $\mathbf{1 5}$ & $35.78 \mathrm{Ba}$ & $34.49 \mathrm{Bb}$ & $33.27 \mathrm{Bc}$ & $34.51 \mathrm{C}$ \\
& $( \pm 0.70)$ & $( \pm 0.31)$ & $( \pm 0.45)$ & $( \pm 1.15)$ \\
\hline 30 & $36.73 \mathrm{Aa}$ & $34.72 \mathrm{Bb}$ & $33.26 \mathrm{Bc}$ & $34.90 \mathrm{~B}$ \\
& $( \pm 0.82)$ & $( \pm 0.60)$ & $( \pm 0.49)$ & $( \pm 1.57)$ \\
\hline Mean & $36.33 \mathrm{a}$ & $35.46 \mathrm{~b}$ & $33.88 \mathrm{C}$ & 35.22 \\
& $( \pm 0.78)$ & $( \pm 1.29)$ & $( \pm 1.02)$ & $( \pm 1.46)$ \\
\hline
\end{tabular}

However, when assessing the interaction between HR and ST, this trend is not observed by setting ST equal to $1000^{\circ} \mathrm{C}$, which shows homogeneity in the $\mathrm{DD}$, while the WA has undergone significant changes 
with the HR increasing. To make this information visually more clear, the data are shown in the graphs of Fig. 4, which contains the results of DDs and WAs for the different HRs and STs. It is important to mention that the density results shown in Fig. 4 (a) are relative to the apparent dry density and the specimens have not yet been sintered. However, this representation was found necessary in order to clarify the understanding in how the differences in DD may lead to changes in other properties, especially the WA (Fig. 4b).

Thus, considering only the $S T$ at $1000^{\circ} \mathrm{C}$, for the same DD of $1.82 \pm 0.02 \mathrm{~g} / \mathrm{cm}$, the WA was significantly higher $(\mathrm{P} \leq 0.05)$. When the $\mathrm{HR}$ of $2^{\circ} \mathrm{C} / \mathrm{min}$ was used $(20.52 \pm 0.49 \%)$ it compares to the rates of $15^{\circ} \mathrm{C} / \mathrm{min}$ and $30^{\circ} \mathrm{C} / \mathrm{min}$, respectively, of $19.25 \pm 0.33 \%$ and $19.19 \pm 0.39 \%$, that did not differ among themselves. At the $1000^{\circ} \mathrm{C}$, by increasing the $\mathrm{HR}$ from $2^{\circ} \mathrm{C} / \mathrm{min}$ to $15^{\circ} \mathrm{C} / \mathrm{min}$, an approximately $6 \%$ reduction in WA was achieved. However, no statistical variation was noted with increasing the $H R$ from $15^{\circ} \mathrm{C} / \mathrm{min}$ to $30^{\circ} \mathrm{C} / \mathrm{min}$.

In order to better understand the relationship between these properties, the Pearson (R) correlation was calculated for all the variables studied. The lower variance by the Tukey test $(P<0.05)$ and correlation superior to $60 \%$ were stipulated, so that only the interaction between WA and AP, as well as WA and DD were chosen, and are represented in Table 4. For WA and AP correlation, they are already well described in the literature $[22,30,31]$, showing that pores interconnected with the surface are those responsible for absorbing water from the environment.

The direct correlation between DD with the other properties, shown in Table 5, such as WA, AP and mechanical strength, makes DD a property of great interest, especially for the ceramic industry [22, 3740]. Indeed, the higher the DD, the smaller the AP becomes and, as a consequence, the smaller the WA the greater the strength. It should be emphasized that packaging degree and DD are different concepts.

However, as there is no variation in the grains density, it is correct to extend the effect of DD correlation to the other properties, as long as one takes care to use the same clay specimens to produce the specimens.

This discussion is pertinent for the correct results evaluation, since the differences found between $\mathrm{HR}$ from $2^{\circ} \mathrm{C} / \mathrm{min}$ to $15^{\circ} \mathrm{C} / \mathrm{min}$ and $30^{\circ} \mathrm{C} / \mathrm{min}$, for ST of 800 and $900^{\circ} \mathrm{C}$, can be explained by differences in $D D$, which presented $R \geq|60 \%|$. However, this fact does not explain the difference in $S T$ at $1000^{\circ} \mathrm{C}(\mathrm{R}=$ $-22 \%)$, so it can be inferred that this difference was due to the increase of the HR.

Table 5

Significant $(P<0.05)$ Pearson correlations $(R)$ and greater than $|60 \%|$ among the evaluated properties

\begin{tabular}{|lll|}
\hline ST $\left({ }^{\circ} \mathrm{C}\right)$ & Water Absorption & \\
\cline { 2 - 3 } & Apparent Porosity & Apparent Dry Density \\
\hline 800 & 0.67 & -0.60 \\
900 & 0.99 & -0.73 \\
1000 & 1.00 & -0.22 \\
\hline
\end{tabular}


Another interesting parameter is the linear shrinkage (LS) with results presented in Table 6, which also indicates that the sintering occurred more efficiently with increasing HR. This property is correlated with the degree of sintering. In a simplified explanation, sintering is a process of mass transport in which material is displaced from its original positions to another, resulting in closing of empty space (porosity reduction) and consequent structural shrinkage [12]. In this way, (LS) is a parameter that helps the sintering degree evaluation, being related to the volumetric reduction of total porosity, i.e., both open and closed pores.

In this context, Table 6 shows that there is an increase in LS with an increase in HR from $2^{\circ} \mathrm{C} / \mathrm{min}$ to $15^{\circ} \mathrm{C} / \mathrm{min}$ and $30^{\circ} \mathrm{C} / \mathrm{min}$. The same trend is observed when analyzing, separately, the interaction between the HR versus ST variables. In all cases, i.e., for all the STs evaluated, there is an increase in LS when comparing the conventional sintering cycle $\left(2^{\circ} \mathrm{C} / \mathrm{min}\right)$ with the fast-sintering cycle $\left(15^{\circ} \mathrm{C} / \mathrm{min}\right.$ and $\left.30^{\circ} \mathrm{C} / \mathrm{min}\right)$.

Table 6

- Sintering linear shrinkage (LS - \%) of specimens as a function of sintering temperature (ST) and heating rates (HR)

\begin{tabular}{|c|c|c|c|c|}
\hline \multirow{2}{*}{$\begin{array}{l}\text { HR } \\
\left({ }^{\circ} \mathrm{C} / \mathrm{min}\right)\end{array}$} & \multicolumn{3}{|l|}{ ST $\left({ }^{\circ} \mathrm{C}\right)$} & \multirow[t]{2}{*}{ Mean } \\
\hline & 800 & 900 & 1000 & \\
\hline \multirow[t]{2}{*}{02} & $0.52 \mathrm{Ac}$ & $1.15 \mathrm{Bb}$ & $1.79 \mathrm{Ba}$ & $1.15 \mathrm{~B}$ \\
\hline & $( \pm 0.16)$ & $( \pm 0.35)$ & $( \pm 0.24)$ & $( \pm 0.58)$ \\
\hline \multirow[t]{2}{*}{15} & $0.60 \mathrm{Ac}$ & $1.43 \mathrm{Bb}$ & $2.15 \mathrm{Aa}$ & $1.39 \mathrm{~A}$ \\
\hline & $( \pm 0.22)$ & $( \pm 0.28)$ & $( \pm 0.23)$ & $( \pm 0.68)$ \\
\hline \multirow[t]{2}{*}{30} & $0.43 \mathrm{Ac}$ & $1.86 \mathrm{Ab}$ & $2.19 \mathrm{Aa}$ & $1.49 \mathrm{~A}$ \\
\hline & $( \pm 0.31)$ & $( \pm 0.57)$ & $( \pm 0.36)$ & $( \pm 0.88)$ \\
\hline \multirow[t]{2}{*}{ Mean } & $0.52 \mathrm{c}$ & $1.48 \mathrm{~b}$ & $2.04 \mathrm{a}$ & 1.35 \\
\hline & $( \pm 0.24)$ & $( \pm 0.50)$ & $( \pm 0.33)$ & $( \pm 0.73)$ \\
\hline
\end{tabular}

With respect to the bending rupture stress results, shown in Table 7, it is revealed that the highest strength of $7.32 \mathrm{MPa}$, was obtained by the sintered specimens with $\mathrm{HR}$ of $15^{\circ} \mathrm{C} / \mathrm{min}$, followed by $6.03 \mathrm{MPa}$ for TA at $2^{\circ} \mathrm{C} / \mathrm{min}$ and 5.07 for $\mathrm{TA}$ at $30^{\circ} \mathrm{C} / \mathrm{min}$. At $30^{\circ} \mathrm{C} / \mathrm{min}$. this might be detrimental, due to the fact that the different crystalline phases, as well as the amorphous matrix, have distinct thermal expansion coefficients. Thus, an excessive increase in HR generates tensions that are responsible for surpassing the material mechanical resistance causing cracks and reducing its mechanical strength [9]. In addition, impairing in strength is also attributed to the volumetric expansion caused by the quartz allotropic 
transformation, in the sand, which at higher HRs is capable of generating stresses above those the products may support.

Table 7

- Bending rupture stress (MPa) of specimens as a function of sintering temperature (ST) and heating rates (HR)

\begin{tabular}{|c|c|c|c|c|}
\hline \multirow{2}{*}{$\begin{array}{l}\text { HR } \\
\left({ }^{\circ} \mathrm{C} . \mathrm{min}^{-1}\right)\end{array}$} & \multicolumn{3}{|l|}{ ST $\left({ }^{\circ} \mathrm{C}\right)$} & \multirow[t]{2}{*}{ Mean } \\
\hline & 800 & 900 & 1000 & \\
\hline \multirow[t]{2}{*}{02} & $4.99 \mathrm{Ab}$ & $5.84 \mathrm{Bb}$ & $7.26 \mathrm{Ba}$ & $6.03 \mathrm{~B}$ \\
\hline & $( \pm 0.25)$ & $( \pm 0.44)$ & $( \pm 1.10)$ & $( \pm 1.17)$ \\
\hline \multirow[t]{2}{*}{15} & $5.47 \mathrm{Ac}$ & $7.70 \mathrm{Ab}$ & $8.79 \mathrm{Aa}$ & $7.32 \mathrm{~A}$ \\
\hline & $( \pm 0.35)$ & $( \pm 0.99)$ & $( \pm 0.97)$ & $( \pm 1.62)$ \\
\hline \multirow[t]{2}{*}{30} & 4.86 $\mathrm{Aa}$ & $4.80 \mathrm{Ca}$ & $5.55 \mathrm{Ca}$ & $5.07 \mathrm{C}$ \\
\hline & $( \pm 0.94)$ & $( \pm 0.83)$ & $( \pm 1.85)$ & $( \pm 1.30)$ \\
\hline \multirow[t]{2}{*}{ Mean } & $5.10 \mathrm{c}$ & $6.11 b$ & $7.2 \mathrm{a}$ & 6.14 \\
\hline & $( \pm 0.64)$ & $( \pm 1.44)$ & $( \pm 1.89)$ & $( \pm 1.65)$ \\
\hline
\end{tabular}

The aforementioned results clearly demonstrate that sintered samples at higher HRs exhibited greater densification rates, assessed indirectly through the presented properties, than samples sintered at lower HRs. This shows that the rate of material transport depends not only on the ST but also on the HR. Moreover, the HR has such a significant influence on the rate of material transport that it exceeds the effect of reducing the sintering time.

Dilatometry experiments were performed with the clay body using three sintering cycles with different $\mathrm{HRs}$ of $2^{\circ} \mathrm{C} / \mathrm{min}, 15^{\circ} \mathrm{C} / \mathrm{min}$ and $30^{\circ} \mathrm{C} / \mathrm{min}$. Corresponding dilatograms are shown in Fig. 5 . Regarding this figure, it is important to mention that the dilatometry tests were repeated and the same behavior was observed.

The curves in Fig. 5 describe similar qualitative behavior. In fact, they correspond to the same events, but with different HR and ST intensities, so that some events occur at higher temperatures for higher heating rates. The shifting in temperature observed in Fig. 5 was expected, since the temperature sensor of the equipment indicates the environment temperature in which the sample is located. Due to the thermal gradient experienced by any material subjected to heating, the environment temperature does not necessarily match the temperature of the sample. Thus, HRs rates should correspond to higher temperature gradients. 
After initial shrinkage, caused by elimination of free and adsorbed water, the sintering starts producing kaolinite dehydroxylation. At this moment, there is an increase of particles specific surface area [24], resulting consolidation of the sintered structure and an increase and crystallinity loss, which may favor mass transport. Simultaneously, the quartz allotropic transformation, indicated by the structure expansion, occurs at different temperatures as a function of $\mathrm{HR}$, being 575,598 and $618^{\circ} \mathrm{C}$ at $2^{\circ} \mathrm{C} / \mathrm{min}$, $15^{\circ} \mathrm{C} / \mathrm{min}$ and $30^{\circ} \mathrm{C} / \mathrm{min}$ respectively.

After the complete kaolinite dehydroxylation, the liquid phase begins to form through eutectics reaction involving the silica contained in the metacaulinite and the alkali oxides contained in the potassic feldspars [20]. At this stage there is the greatest intensity discrepancy of LS values displayed in Table 6, when comparing the $\mathrm{HR}$ of $2^{\circ} \mathrm{C} / \mathrm{min}$ with $15^{\circ} \mathrm{C} / \mathrm{min}$ and $30^{\circ} \mathrm{C} / \mathrm{min}$. The end of this stage can be identified by the change in the curve slope, initiating the spinel and/or primary mullite formation [41-44].

The dependence that the sintering rate has on the HR has already been reported in metals and ceramics. Silva et al. [45] found that the shrinkage rate of hard metal structures (WC-Co) shows a strong dependence on HR. Saleiro and Holanda [46] identified that a red clay body sintering at HRs of 1,10 and $20^{\circ} \mathrm{C} /$ min culminated in similar properties, favoring energy savings. Santos et al. [47] sintered hard metal alloys via pulsed plasma with $\mathrm{HRs}$ above $50^{\circ} \mathrm{C} / \mathrm{min}$ and found that the structure densification rate has a HR dependence. In fact, it is well known that pulsed plasma sintering can densify structures in short time intervals and one of the characteristics of this technique is the high HR employed.

Jones and Miles [48] and Harmer and Brook [49], cited by Johnson et al. [50], sintered alumina materials at high $\mathrm{HRs}$, between $40^{\circ} \mathrm{C} / \mathrm{min}$ and $200^{\circ} \mathrm{C} / \mathrm{min}$, and reported high densification rates under these conditions. In addition, they observed that grain sizes were significantly lower when compared to sintering at slower HRs. These authors attributed the high densification rates and the finer grain sizes to the suppression of surface diffusion occurring by the rapid passage through the temperature regime where surface diffusion rate is intense, avoiding the deleterious effects of this process [51, 52].

In the conventional sintering process, much of the time is spent in temperature ranges where the effects of grain growth, through surface diffusion, outweigh the densification produced by diffusion in grain boundaries and in the crystalline lattice itself. Other studies $[53,54]$ reaffirm that grain growth reduces the driving force for sintering. This is explained by the increase in the average distance required for diffusion, where mass transfer from the grain contours to the neck formation occurs, which is the mechanism responsible for porosity reduction $[55,56]$.

\section{Summary And Conclusions}

A comparison between different sintering cycles at 800,900 and $1000^{\circ} \mathrm{C}$ with distinct heating rates from relatively slow $2^{\circ} \mathrm{C} / \mathrm{min}$ to a fast $30^{\circ} \mathrm{C} / \mathrm{min}$, revealed significant differences in technological properties of a typical Brazilian ceramic clay body used in red bricks, blocks, roofing and floor tiles. 
- Higher heating rates during the sintering of red clay ceramics make it possible to obtain products with superior technological properties. This is an unprecedented conclusion for common red ceramics, based on promising results that evidenced, in a clear and detailed way, the benefits of rapid sintering cycle application for traditional bricks production.

- The practice of reducing the sintering cycle time by raising the heating rate may become a major technological advance, enabling environmental gains for the entire Brazilian red ceramic industrial sector involved, as well as economic benefits, through energy consumption reduction in the sintering stage associated with productivity increase.

- It should be noted that, despite the promising results of this laboratory-scale work, it is still necessary to study the inclusion of natural gas and the use of roller kilns that are typical procedures in the industrial process of sintering bricks at higher heating rates.

\section{Declarations}

Funding: Not applicable

Conflicts of interest/Competing interests: Not applicable

Availability of data and material: Not applicable

Code availability: Not applicable

Ethics approval: Not applicable

Consent for publication: All authors consent to the publication of this manuscript.

Authors' contributions: Carlos Alberto de Oliveira Guimarães and Sergio Neves Monteiro: Methodology and Investigation; Lucas Fonseca Amaral and Claudio Luiz Melo Souza: Writing-original draft preparation and Methodology; Angelus da Silva and José Nilson: Methodology; Geovana Carla Delaqua: Writing-review and editing; Afonso R. G. de Azevedo: Writing-review and editing and Supervision; Carlos Maurício Fontes Vieira and Sergio Neves Monteiro: Supervision.

\section{References}

1. Bustamante GM, Bressiani JC (2000) : Ceramic tile manufacturing technology.Cerâmica Industrial, 5 (3)

2. Alexandre J, de Azevedo ARG, Xavier G, de Pedroti C, Vieira LG, Monteiro SN (2014) Study of a Clayey Soil Used in the Fabrication of Red Ceramics in Campos Dos Goytacazes, Brazil. Mater Sci Forum 798-799. 15-20. https://doi.org/10.4028/www.scientific.net/msf.798-799.15

3. National Association of Ceramic Industry (ANICER). Annual Report (2020) $47 p$

4. Brazilian Ministry of Mines and Energy (MME). Statistical Yearbook: Non-metallic transformation sector. Secretariat of Geology, Mining and Mineral Transformation. Brasília (2021) $102 p$ 
5. Vieira CMF, da Silva PRN, da Silva FT, Capitaneo JL, Monteiro SN (2005) : Microstructural Evaluation and Properties of a Ceramic Body for Extruded Floor Tile. Matéria, v. 10, n. 4 pp. 526 - 536 (In Portuguese)

6. Babisk MP, Amaral LF, Ribeiro LDS, Vieira CMF, Prado USD, Gadioli MCB, Garcia Filho F (2020) Evaluation and application of sintered red mud and its incorporated clay ceramics as materials for building construction. J Mater Res Technol 9:2186-2195

7. Garcia-Valles M, Alfonso P, Martínez S, Roca N (2020) Mineralogical and Thermal Characterization of Kaolinitic Clays from Terra Alta (Catalonia, Spain). Minerals 10:142. doi:10.3390/min10020142

8. Silva AC, Méxas MP, Quelhas OLG (2017) Restrictive factors in implementation of clean technologies in red ceramic industries. J Clean Prod. https://doi.org/10.1016/j.jclepro.2017.09.086

9. Qin M, Tian Y, Hao H, Li, Guomin Z, Wu Y, Bai Y (2020) The Effect of Sintering Temperature on Phase Evolution and Sintering Mechanism of Ceramic Proppants with $\mathrm{CaCO}_{3}$ Addition. Materials Research. https://dx.doi.org/10.1590/1980-5373-mr-2019-0602

10. Liu S, Guan X, Xu SZC, Li H, Zhang J (2017) Sintering red mud based imitative ceramic bricks with C02 emissions below zero. Mater Lett. https://doi.org/10.1016/j.matlet.2016.12.028

11. Silva AC, Carolina SD, Sousa DN, Silva EMS (2019) Feldspar production from dimension stone tailings for application in the ceramic industry. Journal of Materials Research and Technology. https://doi.org/10.1016/j.jmrt.2018.02.011

12. Monteiro SN, Vieira CMF (2004) Solid state sintering of red ceramics at lower temperatures. Ceramics International, v 30:381-387. https://doi.org/10.1016/S0272-8842(03)00120-2

13. de Azevedo MC, Marvila MT, Delaqua GCG, Amaral LF, Colorado H, Vieira CMF (2021) : Economy analysis of the implementation of extruded tiles fabrication in a ceramic industry containing ornamental rock waste https://doi.org/10.1111/ijac.13728

14. Delaqua GCG, Marvila MT, Souza D, Rodriguez RSJ, Colorado HA, Vieira CMF (2020) Evaluation of the application of macrophyte biomass Salvinia auriculata Aublet in red ceramics. J Environ Manage 275:111253. https://doi.org/10.1016/j.jenvman.2020.111253

15. Ma X, Tian YM, Zhou Y, Wang KY, Chai YS, Li ZG (2016) Sintering temperature dependence of lowcost, low-density ceramic proppant with high breakage resistance. Mater Lett 180:127-9

16. Ma HQ, Tian YM, Zhou Y, Li GM, Wang KY (2018) Effective reduction of sintering temperature and breakage ratio for a low-cost ceramic proppant by feldspar addition. Int J Appl Ceram Technol 15:191-6

17. Cargnin M, Ulson de Souza SMAG, Ulson de Souza AA, de Noni A Jr (2015) Modeling and simulation of the effect of the firing curve on the linear shrinkage of ceramic materials: laboratory scale and industrial scale. Brazilian Journal of Chemical Engineering Vol 32(02):433-443. dx.doi.org/10.1590/0104-6632.20150322s00002876

18. Salminen E, Mjöberg J, Anhava J (2019) : Nordic Ceramics Industry Best Available Technique (BAT), Copenhagen: Nordisk Ministerråd 81 p. http://dx.doi.org/10.6027/TN2019-510 
19. Kruth J-P, Leu MC, Nakagawa T (1998) Progress in Additive Manufacturing and Rapid Prototyping. Progress in Additive Manufacturing and Rapid Prototyping - CIRP Annals, v.47 pp. 525-540, https://doi.org/10.1016/S0007-8506(07)63240-5

20. Azevedo ARG, França BR, Alexandre J, Marvila MT, Zanelato EB, Xavier EB (2018) Influence of sintering temperature of a ceramic substrate in mortar adhesion for civil construction. Journal of Building Engineering. https://doi.org/10.1016/j.jobe.2018.05.026

21. Vieira CMF, Sanchez R, Monteiro SN, Lalla N, Quaranta N (2013) Recycling of electric arc furnace dust into red ceramic. Journal of Materials Research and Technology. https://doi.org/10.1016/j.jmrt.2012.09.001

22. Amaral LF, Carvalho JPRG, Silva BM, Delaqua GCG, Monteiro SN, Vieira CMF (2019) Development of ceramic paver with ornamental rock waste. Journal of Materials Research and Technology. https://doi.org/10.1016/j.jmrt.2018.05.009

23. Monteiro SN, Vieira CMF (2004) Influence of firing temperature on the ceramic properties of clays from Campos dos Goytacazes, Brazil. Applied Clay Science, v 27:229-234. https://doi.org/10.1016/j.clay.2004.03.002

24. Vieira CMF, Peçanha LA Jr, Monteiro SN (2006) Effect of kaolinitic clays from the State of Rio de Janeiro in the composition of whiteware floor tile bodies. Cerâmica 52:138-145. (In Portuguese).

25. Dondi M, Guarani I, Ligas GP, Palomba M, Raimondo M, Uras I (2010) Chemical, mineralogical and ceramic properties of kaolinitic materials from the Tresnuraghes mining district (Western Sardinia, Italy). Appl Clay Sci 18:145

26. Brazilian Association of Technical Standards - ABNT (Associação Brasileira de Normas Técnicas) (2016) NBR 7181 - Soil - Grain size analysis. ABNT, Rio de Janeiro. (In Portuguese).

27. Brazilian Association of Technical Standards - ABNT (Associação Brasileira de Normas Técnicas) (2017) NBR 6459 - Soil - Liquid limit determination. ABNT, Rio de Janeiro. (In Portuguese).

28. Brazilian Association of Technical Standards - ABNT (Associação Brasileira de Normas Técnicas). NBR 7180 - Soil - Plasticity limit determination: ABNT (2016) ; (In Portuguese)

29. ASTM - (1997) American Society for Testing and Materials, C373,

30. Johari I, Said S, Abu B, Bakar BH, Ahmad Z (2010) Effect of the change of firing temperature on microstructure and physical properties of clay bricks from Beruas (Malaysia). Sci Sinter 42. $10.2298 /$ SOS1002245J

31. Vijayaragavan R, Mullainathan S (2011) Effect of Sintering Temperature on the Properties and Microstructure of a Ceramic Product. Material Science Research India Vol. 8(2) 321-325. Available from: http://www.materialsciencejournal.org/?p=2668

32. Fontes Vieira CM, Monteiro SN (2019) Firing behavior of the clay fraction of a natural kaolinitic clay: are they different? Materials Research 22. https://doi.org/10.1590/1980-5373-MR-2019-0172

33. Dondi M (2003) Technological Characterization of Clay Materials: Experimental Methods and Data Interpretation. Journal Ceramic International, 55 - 59 
34. Heystek H (1964) Desired properties of clay minerals in ceramics. American Ceramic Society Convention, Chicago, Abril

35. Marsigli M, Dondi M (1997) Plasticity of Italian clays for bricks and how they are expected to react during the shaping process. L'Industria dei Laterizi 46:214

36. Ribeiro MJ, Ferreira JM, Labrincha JA (2005) Plastic behaviour of different ceramic pastes processed by extrusion. Ceram Int 31(4):515-519. DOI:10.1016/j.ceramint.2004.06.016

37. Dinger DR (2001) Particle Calculations for ceramists. Morris Publishing, Kearney - NE, USA, p 126

38. Abubakar M, Muthuraja A, Rajak DK, Ahmad N, Pruncu Cl, Lamberti L, Kumar A (2020) Influence of Firing Temperature on the Physical, Thermal and Microstructural Properties of Kankara Kaolin Clay: A Preliminary Investigation. Materials 13:1872. doi:10.3390/ma13081872

39. Girondi GD, Marvila MM, de Azevedo ARG, de Souza CC, Souza D, de Brito J, Vieira CMF (2020) Recycling potential of powdered cigarette waste in the development of ceramic materials. J Mater Cycles Waste Manag 22(5):1672-1681

40. Nigay PM, Cutard T, Nzihou A (2017) The impact of heat treatment on the microstructure of a clay ceramic and its thermal and mechanical properties. Ceram Int 43:1747-1754. https://doi.org/10.1016/j.ceramint.2016.10.084

41. Liu K, Thomas G (1994) Time-Temperature-Transformation Curves for Kaolinite-a-Alumina. Journal of American Ceramic Society. https://doi.org/10.1111/j.1151-2916.1994.tb09755.x

42. Behera PS, Bhattacharyya S (2020) Effect of different alumina sources on phase formation and densification of single-phase mullite ceramic - Reference clay alumina system.Mater Today Commun 101818

43. Chen Y-F, Wang MC, Hon M-H (2004) Phase Transformation and Growth of Mullite in Kaolin Ceramics. J Eur Ceram Soc 24:2389-2397. 10.1016/S0955-2219(03)00631-9

44. Navarro LCR, Menezes RR, Kiminami RHGA (2014) Microwave sintering of mullite-Al2O3 from kaolin precursor. Materials Research 17(6). https://doi.org/10.1590/1516-1439.281114

45. da Silva AGP, Schubert WD, Lux B (2001) The role of the binder phase in the WC-Co sintering. Materials Research 4(2). https://doi.org/10.1590/S1516-14392001000200003

46. Saleiro GT, Holanda JNF (2012) Processing of red ceramic using a fast-firing cycle. http://dx.doi.org/10.1590/S0366-69132012000300018. (In Portuguese). Cerâmica

47. Santos A, Skury C, Silva ALD A.G.P.: Spark Plasma Sintering of a Hard Metal Powder Obtained from Hard Metal Scrap. Materials Research, v. 20 (2017)1980-5373. https://doi.org/10.1590/1980-5373MR-2016-1035

48. Jones W, Miles LJ (1971) : Proceedings of the British Ceramic Society, 19 Production of $\beta-\mathrm{Al}_{2} \mathrm{O}_{3}$ Electrolyte, in: Proc. Brit. Ceram. Soc. Vol. 19, Stoke-on-Trent, Eng. land (1971)

49. Harmer MP, Brook RJ (1981) Fast firing-microstructural benefits. J Br Ceram Soc 80:147-8

50. Johnson DL, Kuczynski GC, Miller AE, Sargent GA (1984) Ultra-Rapid Sintering.Materials Science Research243 
51. Zhang H, Xu Y, Wang B, Zhang X, Yang J, Niihara K (2015) Effects of heating rate on the microstructure and mechanical properties of rapid vacuum sintered translucent alumina. Ceram Int 41(9):12499-12503. doi:10.1016/j.ceramint.2015.05.136

52. Cokic SM, Vleugels J, Van Meerbeek B, Camargo B, Willems E, Li M, Zhang F (2020) Mechanical properties, aging stability and translucency of speed-sintered zirconia for chairside restorations. Dent Mater. doi:10.1016/j.dental.2020.04.026

53. Greskovich A, Lay KW (1972) Grain Growth in Very Porous Al2O3 Compacts. Journal of American Ceramic Society 55:142

54. Kim DH, Kim CH (1993) Effect of Heating Rate on Pore Shrinkage in Yttria-doped Zirconia. Journal of American Ceramic Society 76:1877

55. Palmeira AA, Cangani MP, Rodrigues D Jr, Strecker K, dos Santos C (2021) Influence of sintering parameters on the microstructure and mechanical properties of nanosized 3Y-TZP ceramics. Cerâmica 67:14-21. https://doi.org/10.1590/0366-69132021673812908 (In Portuguese)

56. Castro RHR (2019) Controlling sintering and grain growth of nanoceramics. Cerâmica 65:122-129. https://doi.org/10.1590/0366-69132019653732573 (In Portuguese)

\section{Figures}

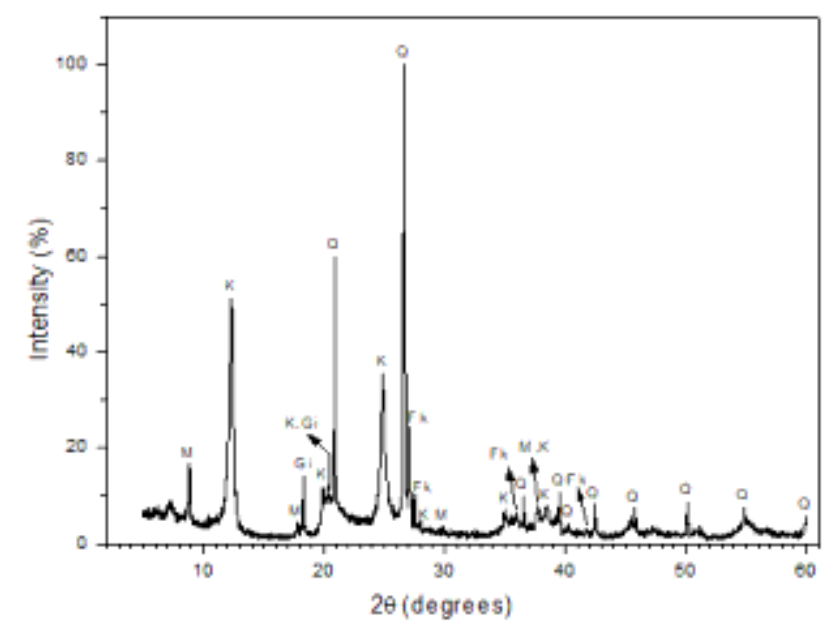

\section{Figure 1}

X-ray diffraction of the clayey body: $\mathrm{M}=$ muscovite, $\mathrm{K}=$ kaolinite, $\mathrm{Gi}=$ gibbsite, $\mathrm{Q}=$ quartz, $\mathrm{Fk}=$ potassium feldspar. 


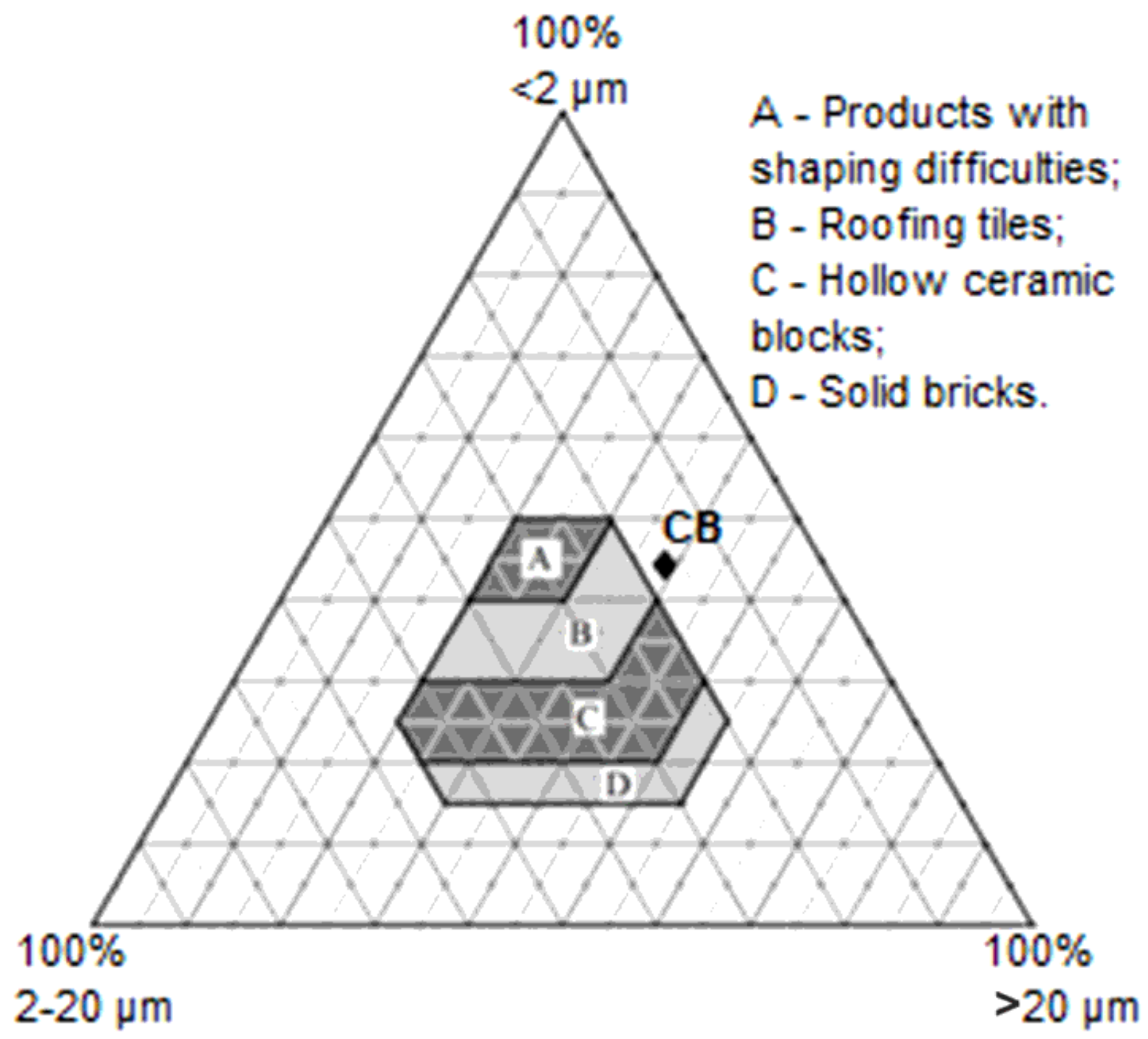

Figure 2

Granulometric distribution of clayey body on Winkler diagram 


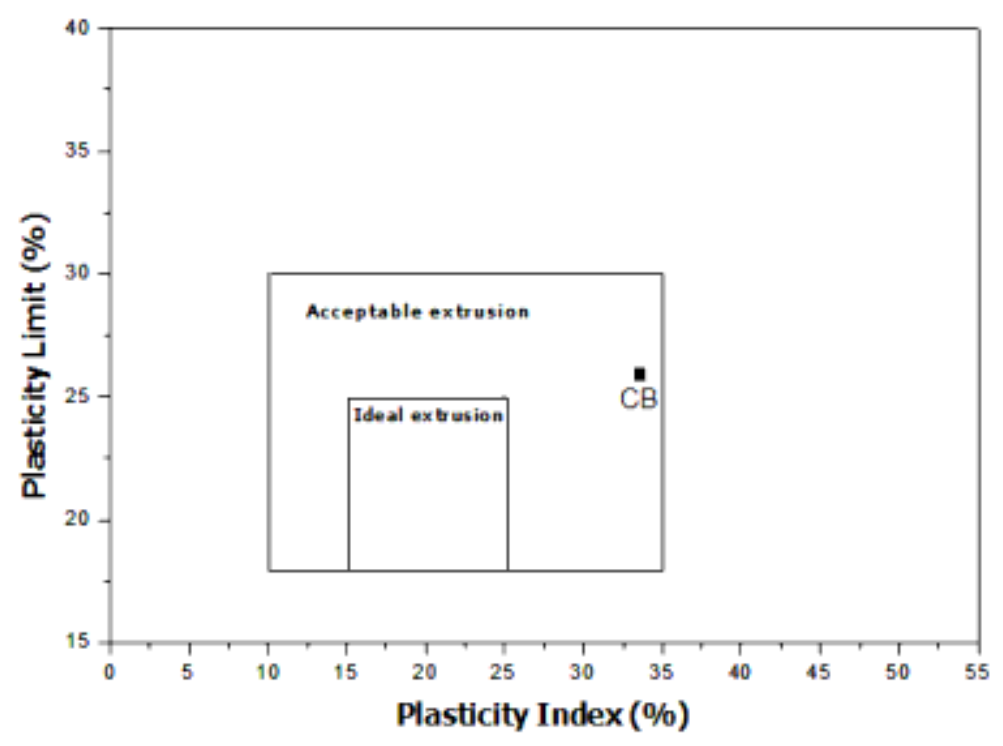

Figure 3

Extrusion prognosis by Atterberg indices
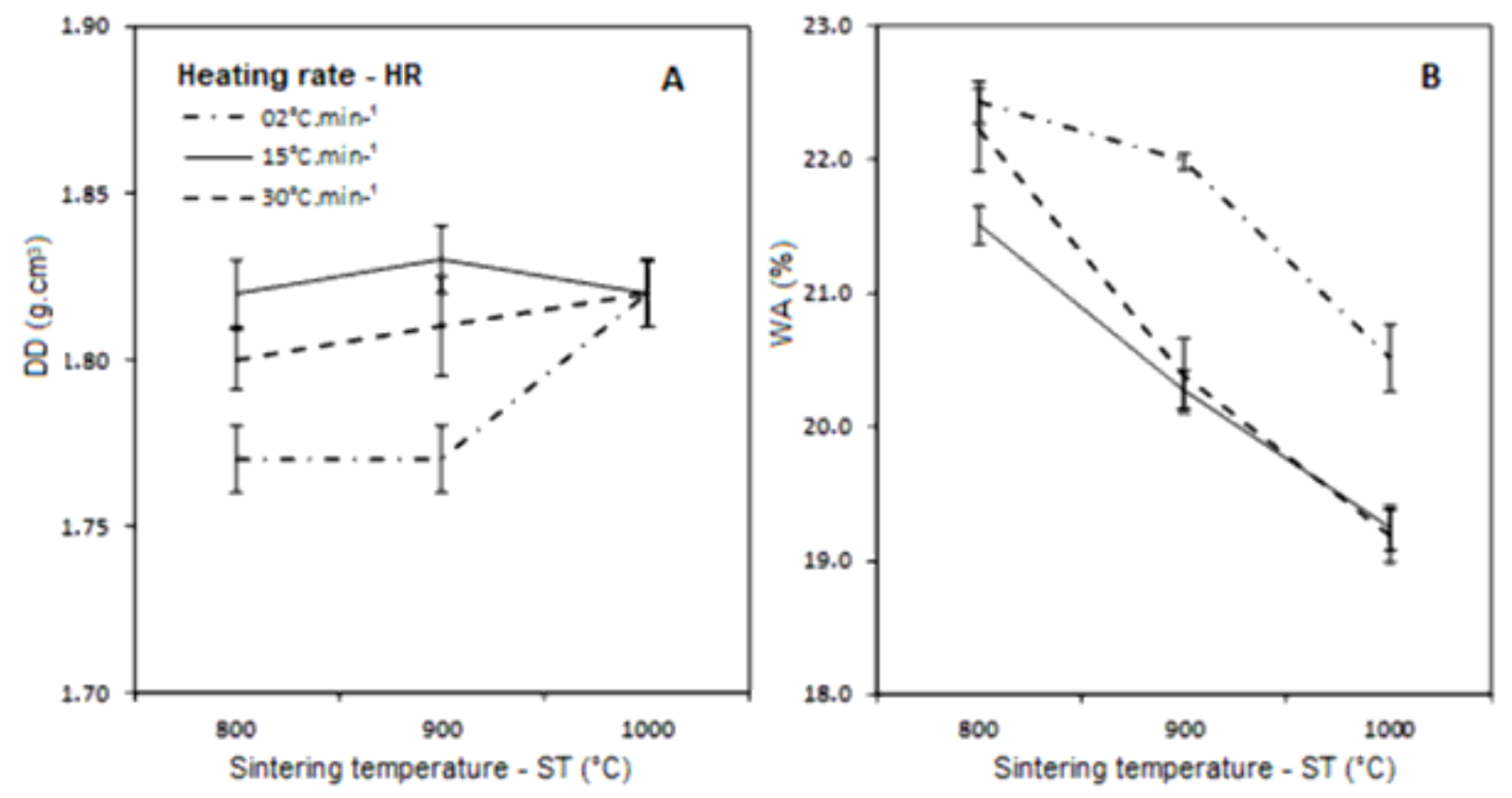

Figure 4

(a) Apparent dry density (DD) and (b) water absorption (WA) of specimens subjected to different sintering temperatures (ST) and heating rates (HR) on laboratorial furnace $(n=13$; Tukey, $P \leq 0.05)$. 


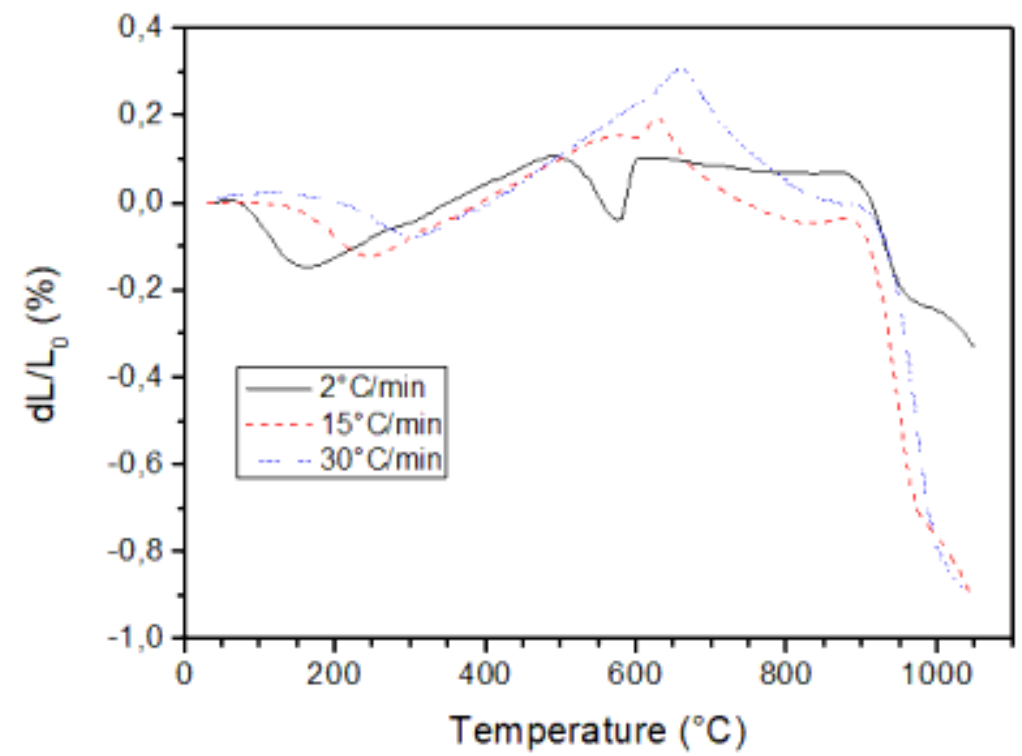

Figure 5

Clay body dilatograms subjected to different heating rates (HR) 